\title{
非線形要素の時系列相関解析に関する一考察
}

\author{
林順雄 \\ 日立製作所習志野工場 習志野市東習志野町 1-1 \\ (昭和 43 年 7 月 20 日受)
}

\section{On a Method of Correlation Analysis for Nonlinear Elements}

\author{
Nobuo HAYASH \\ (Narashino Works, Hitachi Ltd, Narashino) \\ (Received July 20, 1968)
}

In this paper, some applications of the method of correlation analysis for the identification of nonlinear elements with zero-memory property are discussed. The estimation of nonlinear characteristics by correlation methods is generally very difficult. It is well-known that the conventional correlation method gives the statistically linearized characteristics of general nonlinear systems, however further details about nonlinear characterics of elements are not given by this method.

A convenient method for the estimation of the nonlinear characteristics of elements is proposed. An algebraic treatment of the equation for the evaluation of nonlinearity factors $a_{n}$ is shown. The method proposed here is very easy and rational in comparison with the method of multiple regression analysis for this problem. Finally, some numerical examples are shown.

\section{1. 緒言}

線形系の相関解析による動特性推定理論については， いち和らその成果もあがっているし文献も多い。これ らの問題をひとと和り考察した後に扣ける課題として だれしも思いあたるのは, 非線形特性を時系列相関解 析によって推定し得ないであうらかといら問題拉よび 分布常数系の相関解析の問題であろう．ここでは非線 形要素の相関解析の問題に限定して考察を加兄る。は じめに相関法を用いて非線形特性または非線形度を推 定することの意義，および相関法を用いない場合に比 較してどのような長所があり得るものかについて考え てみる.

相関法を用いて自動制御系ないし自動制御要素の特 性認知を行なら手法の長所としては，周知のと新り系 の定常動作状態つまりオンラインに晾ける特性測定を 可能ならしめることがある．また別の利点としては低 レベルの信号を用い得るので，飽和形の非線形要素に ついては，非線形性の影響を受けずとその線形部分特 性の測定が可能であることがある．また反面実際の励
振振幅レベルに括ける特性を知り得る利点も考兄られ る.さらにまたオンラインに和ける定常励振振幅がそ の要素の飽和域にはいる場合や, 非線形要素が $3 / 2$ 乗 特性のごときものであるさいには, 非線形安定論を適 用するためにも，相関法による非線形要素の特性認知 が行なえれば便利である。これに反し，過渡応答法や 周波数応答法ではとかく励振振幅が大きくなりやすく， またオンライン測定ができない欠点がある。また非線 形度を知ることの意義は，たとえば飽和形であること が既知の要素が, 時間平均的にどの程度まで非線形領 域まで励振されているかを示す尺度を得ることにある。 周知のように線形系の相関法による動特性推定手法 を非線形系に適用した場合には，その統計的線形化特 性を推定することになる。したがってこの統計的線形 化特性のみ知秃ば十分な場合には, 従来の相関法の適 用の久で目的を達成できる。しかしながら，たと兊ば 飽和形の非線形要素が時間平均的にどの程度線形領域 て動作しているかの尺度を示す非線形度や，実際の励 振範囲に打ける非線形特性を知るためには，オンライ ン推定可能な相関法の開発が必要で従来の手法のみで 
は不十分なのである．以下においてこの目的に沿った 手法の一つを示すことにする。

\section{2. 非線形系の相関解析の理論}

ここでは簡単のため一変数開ループ系に限定して考 察し，しかも非線形系は Fig. 1 のようにゼロメモリ

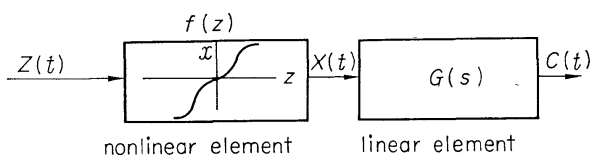

Fig. 1 Unıvariate nonlinear system 形非線形要素と線形要素とに分離でさるものとする。 このような場合には, 線形要素については従来の相関 法で特性認知できるので, 問題は非線形関数 $f(z)$ の推 定に帰着する。

さて入力 $Z(t)$ は正規確率過程に従う確率変数とす る. この場合成立する周知の基本的諸関係式を導入し て説明を加光る。いま任意の時点 $t_{1}, t_{2}$ に打ける $Z(t)$ の同時分布の確率密度 $W_{2}\left(z_{1}, z_{2}\right)$ は次式で与えられ ろ.

$$
\begin{aligned}
W_{2}\left(z_{1}, z_{2}\right) & =\frac{1}{2 \pi \sigma_{z_{1}} \sigma_{z_{2}} \sqrt{1-\rho_{z}{ }^{2}}} \cdot \exp \left[-\frac{1}{2\left(1-\rho_{z}{ }^{2}\right)}\right. \\
& \times\left\{\frac{\left(z_{1}-m_{z_{1}}\right)^{2}}{\rho_{z_{1}}{ }^{2}}+\frac{\left(z_{2}-m_{z_{2}}\right)^{2}}{\sigma_{z_{2}}{ }^{2}}\right. \\
& \left.\left.-2 \rho_{z} \frac{\left(z_{1}-m_{z_{1}}\right)\left(z_{2}-m_{z_{2}}\right)}{\sigma_{z_{1}} \sigma_{z_{2}}}\right\}\right]
\end{aligned}
$$

これは 2 次元正規分布の一般式であるので，記号は自 明であり説明を省略する．これを $z_{1}$ と $z_{2}$ との相関 $\rho_{z}$ に関する直交多項式に展開して $(2)$ 式を得る ${ }^{1}$.

$$
\begin{aligned}
W_{2}\left(z_{1}, z_{2}\right) & =\frac{1}{2 \pi \sigma_{z_{1}} \sigma_{z_{2}}} \cdot \exp \left[-\frac{1}{2}\left\{\left(\frac{z_{1}-m_{z_{1}}}{\sigma_{z_{1}}}\right)^{2}\right.\right. \\
& \left.\left.+\left(\frac{z_{2}-m_{z_{2}}}{\sigma_{z_{2}}}\right)^{2}\right\}\right] \cdot \sum_{n=0}^{\infty} \frac{1}{n !} \\
& \times \rho_{z}^{n} H_{n}\left(\frac{z_{1}-m_{z_{1}}}{\sigma_{z_{1}}}\right) H_{n}\left(\frac{z_{2}-m_{z_{2}}}{\sigma_{z_{2}}}\right)
\end{aligned}
$$

ここで $H_{n}(\zeta)$ はらに関するn次のエルミート多項式 を示す。

さて線形系の場合には, 入力の自己相関と出入力の 相互相関の及を用いて動特性推定を行ならことができ る.ただしスペクトル解析により周波数応答関数を推 定するさいには，推定精度を統計的にはあくする尺度 として coherency $\gamma$ を次式により求めることが多い.

$$
r^{2}=|A(f)|^{2} S_{z z}(f) / S_{x x}(f)
$$

ここで $S_{z z}(f), S_{x x}(f)$ は入力执よ゙出力のパワース ペクトル密度, $A(f)$ は周波数応答関数である. その 場合には $S_{x x}(f)$ を求めるため出力の自己相関を計 算することになるが，この coherency 算出は本質的
に必要なものではない。ところが非線形要素の特性を 求める場合には，出力の自己相関もまた本質的に必要 な情報源となるのである。ここではこの説呮のため， 出力の自己相関の計算式より出発する.

非線形要素のゼロメモリ形であるのが既知とすれば。 時点 $t, t+\tau$ に打ける出力值より 2 次モーメント $B_{x}$ $(t, \grave{t}+\tau)$ を求め机ば以下のようになる.

$$
\begin{aligned}
B_{x}(t, t+\tau) & =\varepsilon\{X(t) X(t+\tau)\} \\
& =\int_{-\infty}^{\infty} \int_{-\infty}^{\infty} f\left(z_{1}\right) f\left(z_{2}\right) W\left(z_{1}, z_{2}\right) d z_{1} d z_{2}
\end{aligned}
$$

ここで $f(z)$ は非線形特性を示し， $\varepsilon$ は期待值演算子 である. $W_{2}\left(z_{1}, z_{2}\right)$ に直交展開式を用いて次式を得 る ${ }^{2)}$.

$$
B_{x}(t, t+\tau)=\sum_{n=0}^{\infty} \rho_{z}^{n}(\tau) a_{1 n} a_{2 n}
$$

ここで $a_{i n}(i=1,2)$ は, $m_{z_{i}}, \sigma_{z_{\imath}}$ の関数でつぎで与え られる。

$$
\begin{aligned}
a_{i n} & =\frac{1}{\sqrt{2 \pi n !} \sigma_{z_{\imath}}} \int_{-\infty}^{\infty} f\left(z_{i}\right) H_{n}\left(\frac{z_{i}-m_{z_{\imath}}}{\sigma_{z_{\imath}}}\right) \exp \\
& \times\left[-\frac{\left(z_{\imath}-m_{z_{\imath}}\right)^{2}}{2 \sigma_{z_{\imath}}{ }^{2}}\right] d z_{i} \\
& =\frac{1}{\sqrt{2 \pi n !}} \int_{-\infty}^{\infty} f\left(\zeta \sigma_{z_{\imath}}+m_{z_{\imath}}\right) H_{n}(\zeta) e^{-\zeta^{2 / 2}} \cdot d \zeta
\end{aligned}
$$

またはつぎのように表現してもよい。

$$
a_{i n}\left(m_{z_{\imath}}, \sigma_{z_{\imath}}\right)=\frac{1}{\sqrt{n !}} \varepsilon\left\{f\left(z_{i}\right) H_{n}\left(\frac{z_{z_{\imath}}-m_{z_{\imath}}}{\sigma_{z_{\imath}}}\right)\right\}
$$

ここで $H_{0}(\zeta)=1$ に注意して, $a_{10}=\varepsilon\left\{f\left(z_{1}\right)\right\}, a_{20}=$ $\varepsilon\left\{f\left(z_{2}\right)\right\}$ を考慮すれば, 出力 $X$ の自己相関関数 $R_{x}$ $(t, t+\tau)$ はつぎのよらになる.

$$
\begin{aligned}
R_{x}(t, t+\tau) & =B_{x}(t, t+\tau)-\varepsilon\left\{f\left(z_{1}\right)\right\} \varepsilon\left\{\left(f z_{2}\right)\right\} \\
& =\sum_{n=1}^{\infty} \rho_{z}{ }^{n}(\tau) a_{1 n} a_{2 n}
\end{aligned}
$$

さらに入力 $z(t)$ が定常的つまり正規定常過程であれ ば（これは実際上は多くの場合成立する）， $m_{z_{1}}=m_{z_{2}}$ $=m_{z}, \sigma_{z_{1}}=\sigma_{z_{2}}=\sigma_{z}$ であるから,$a_{1 n}=a_{2 n}=a_{n}$ となり 次式を得る.

$$
R_{x}(\tau)=\sum_{n=1}^{\infty} \rho_{z}{ }^{n}(\tau) a_{n}^{2}
$$

さていっぽう， 入出力の相互相関 $R_{x z}(\tau)$ はどうな. るか考えてみよう，定義により $R_{x z}(\tau)$ は以下のよう になる。

$$
\begin{aligned}
R_{x z}(\tau) & =\varepsilon\{X(t) Z(t+\tau)\}-\varepsilon\{X(t)\} \varepsilon\{Z(t+\tau)\} \\
B_{x z}(\tau) & =\varepsilon\{X(t) Z(t+\tau)\} \\
& =\int_{-\infty}^{\infty} \int_{-\infty}^{\infty} f\left(z_{1}\right) z_{2} W_{2}\left(z_{1}, z_{2}\right) d z_{1} d z_{2}
\end{aligned}
$$


上述と全く同様の計算過程を経て，次式が得られる.

$$
B_{x z}(\tau)=\sum_{n=0}^{\infty} a_{1 n} b_{n} \rho_{z}^{n}(\tau)
$$

ここで $b_{n}$ は次式で与えられる.

$$
\begin{aligned}
b_{n} & =\frac{1}{\sqrt{2 \pi n !} \sigma_{z}} \cdot \int_{-\infty}^{\infty} z H_{n}\left(\frac{z-m_{z}}{\sigma_{z}}\right) \\
& \times \exp \left[-\frac{\left(z-m_{z}\right)^{2}}{2 \sigma_{z}^{2}}\right] d z
\end{aligned}
$$

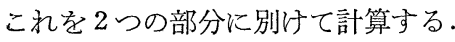

$$
\begin{aligned}
b_{n} & =\frac{1}{\sqrt{2 \pi n !} \sigma_{z}}\left[\int_{-\infty}^{\infty}\left(z-m_{z}\right) H_{n}\left(\frac{z-m_{z}}{\sigma_{z}}\right)\right. \\
& \times \exp \left\{-\frac{\left(z-m_{z}\right)^{2}}{2 \sigma_{z}^{2}}\right\} d z \\
& \left.+m_{z} \int_{-\infty}^{\infty} H_{n}\left(\frac{z-m_{z}}{\sigma_{z}}\right) \exp \left\{-\frac{\left(z-m_{z}\right)^{2}}{2 \sigma_{z}^{2}}\right\} d z\right]
\end{aligned}
$$

$\zeta=\frac{z-m_{z}}{\sigma_{z}}$ とおき, $H_{0}(\zeta)=1, H_{1}=(\zeta)=\zeta$ に注意し $\tau$,

$$
\begin{aligned}
b_{n} & =\frac{1}{\sqrt{2} \pi n !}\left[\int_{-\infty}^{\infty} H_{1}(\zeta) H_{n}(\zeta) e^{-\zeta^{2} / 2} d \zeta\right. \\
& \left.+m_{z} \int_{-\infty}^{\infty} H_{0}(\zeta) H_{n}(\zeta) e^{-\zeta^{2} / 2} d \zeta\right]
\end{aligned}
$$

ここでェルミート多項式 $H_{n}(\boldsymbol{\zeta})$ の直交性より次式を 得る.

$$
\left.\begin{array}{ll}
b_{0}=m_{z}, & b_{1}=1, \\
b_{n}=0, & (n \geq 2)
\end{array}\right\}
$$

壮っきょく，つぎの関係が成立ずる $\left(a_{0}=m_{x}, R_{z}(\tau)\right.$ $=\sigma_{z}{ }^{2} \rho_{z}(\tau)$ 飞注意).

$$
\begin{aligned}
& B_{x z}(\tau)=a_{0} m_{z}+a_{1} \rho_{z}(\tau) \\
& R_{x z}(\tau)=a_{1} \rho_{z}(\tau)=\frac{a_{1}}{\sigma_{z}{ }^{2}} R_{z}(\tau)
\end{aligned}
$$

以上の結果は既知のことがらであるが, 以下本題の 考察に得る.上式から見られると和り, 相互相関执よ び入力自己相関を用いたさいは， $a_{1}$ の推定しか行な えない.つまり一般には任意の非線形系に対する統計 的線形化動特性が推定されるだけである.このように して非線形特性の推定には出力の自己相関が本質的な 情報源となるのが諒解される. 具体的には出力和よび 入力の自己相関より非線形性の推定を行ない, 相互相 関より位相ないし遅延時間の推定を行ならとよいと考 えられる. まず最初に（18）式より $a_{1}$ を精度良く推 定することを行なら。

ての 1 つの時点につき $a_{1}$ を求めるよりは，適当な $M$ 個の $\tau$ 决 (18) 式を作り，最小自乗法によって $a_{1}$ を推定するほうが精度上好しい，念のため書けば，

$$
\left.\begin{array}{l}
R_{x z}\left(\tau_{1}\right)=\hat{a}_{1} \rho\left(\tau_{1}\right)+\varepsilon_{1} \\
R_{x z}\left(\tau_{M}\right)=\hat{a}_{1} \rho\left(\tau_{M}\right)+\varepsilon_{M}
\end{array}\right\}
$$

として $\Sigma \varepsilon_{i}{ }^{2}$ が最小となるように $\hat{a}_{1}$ を推定する。こ こで $\varepsilon_{i}$ 性正規分布に従う誤差として报える. 周知の 手法でもあり，これ以上の説明は省略する.

つぎに $a_{n}(n=2,3, \cdots, l)$ を推定し， $a_{n}$ と $a_{1}$ とよ り非線形特性を推定する手法を考学る。な和類形的な 非線形要素については， $a_{n}$ が算出されているので （たとえば文献 2) 参照）これらの比較で大略の非線 形性推定は $a_{n}$ の及でも可能である。また $a_{n}^{2}$ は (6) の示すと打り $1 / n$ ! で評価され，いっぽう $\rho_{z}^{n}(\tau)$ は $\tau$ 执よ゙nの大きい所できわめて小となるので， $\tau$ の 小さい部分の $R_{x}(\tau)$ が重要な情報を与光ることに気 がつく:つまり非線形性に基づく高周波の発生は $R_{x}(\tau)$ の $\tau=0$ の近傍で顕著となるので, $\tau$ の 0 近傍 は原理的には重要であるが, 後に示す簡便推定法では この近傍はかえって使いにくいことがある.

\section{3. 非線形特性認知の一手法}

前述のと郝りまず $a_{n}$ の推定法を考光，つぎに（6） 式を用いて $f(z)$ を推定する方法について述べる.

\section{$3 \cdot 1 \boldsymbol{a}_{n}$ の推定の一手法}

入力および出力の自己相関の久を用いるときは， $a_{n}{ }^{2}$ を大略はあく乙得るに過ぎないことが検討の結果明ら かとなったのでここれは後に簡便推定法として述べる ことにし，ここでは Fig. 2 のような回路により特性

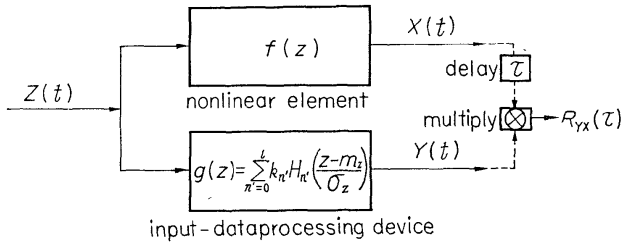

Fig. 2 The principle diagram of identification method

認知を行ならことを考皇る。

Fig. 2 のように $g(z)$ を特性既知の非線形要素とし, $Y(t), X(t), Z(t)$ より $f(z)$ を推定する. この場合も しも $g(z)$ を可変にできれば, $X(t)-Y(t)=0$ (厳密 には平均収束の意味）とする $g(z)$ で $f(z)$ を推定で きるので，手法的になんの目新しさもない。しかし $g(z)$ を調整したりするのは機構的にも複雑であるの でここでは $g(z)$ を最初から一定の非線形特性に固 定した場合の $f(z)$ の推定法について考察する。すな わち $g(\boldsymbol{z})$ なる非線形要素は, 有限個数のエルミート 直交多項式を用いて，つぎのように表現されるよう構 成する（すなわち，エルミート多項式の性質から考克 て, $g$ 注 $M$ 次多項式で表現される非線形要素とな る). 


$$
g(z)=g\left(m_{z}+\zeta \sigma_{z}\right)=g^{*}(\zeta)=\sum_{n^{\prime}=0}^{M} k_{n^{\prime}} H_{n^{\prime}}(\zeta)
$$

実例として $k_{0}=k_{1}=\cdots=k_{6}=1, M=6$ とすれば，こ の場合の $g^{*}(\zeta)$ はつぎのようになる。

$$
\begin{aligned}
g^{*}(\zeta) & =\sum_{n^{\prime}=0}^{6} H_{n^{\prime}}(\zeta)=\zeta^{6}+\zeta^{5}-14 \zeta^{4}-9 \zeta^{3} \\
& +40 \zeta^{2}-13 \zeta-12
\end{aligned}
$$

$m_{z}=0$ なるときは，アナログ素子で $g^{*}(\zeta)$ を構成し 得る可能性もあるが，一般には $m_{z} \neq 0$ なので $g^{*}(\zeta)$ はディジタル的に構成すべきであるう。いわばデータ 処理用の数値フィルタに類似したもの之考兄てよい. これは一見複雑のようであるが, 前述の $g(z)$ 可変と し $\varepsilon|X(t)-Y(t)|^{2}$ を最小にするような帰還方式パラ メータ調整システムに比較すれば, 原理的にはるかに 簡単なものである。さてこのよらにデータ処理を行な ってから， $B_{x y}(t, t+\tau)$ と $R_{x y}(t, t+\tau)$ を求める.

$$
B_{x y}(t, t+\tau)=\int_{-\infty}^{\infty} \int_{-\infty}^{\infty} f\left(z_{1}\right) g\left(z_{2}\right) \dot{W_{2}}\left(z_{1}, z_{2}\right) d z_{1} d z_{2}
$$

前述と同様にして, $W_{2}\left(z_{1}, z_{2}\right)$ の直交展開を用いると，

$$
\begin{aligned}
B_{x y}(t, t+\tau) & =\sum_{n^{\prime}, n} \int_{-\infty}^{\infty} \int_{-\infty}^{\infty} f\left(m_{z_{1}}+\zeta_{1} \sigma_{z_{1}}\right) k_{n^{\prime}} H_{n^{\prime}}\left(\zeta_{2}\right) \\
& \times \frac{1}{2 \pi} \exp \left[-\frac{\zeta_{1}{ }^{2}+\zeta_{2}{ }^{2}}{2}\right] \rho_{z}{ }^{n} \\
& \times \frac{1}{n !} H_{n}\left(\zeta_{1}\right) H_{n}\left(\zeta_{2}\right) d \zeta_{1} d \zeta_{2} \\
& =\sum_{n^{\prime}, n} k_{n^{\prime}} \rho_{z^{n}} a_{1 n} \frac{1}{\sqrt{2 \pi n !}} \\
& \times \int_{-\infty}^{\infty} H_{n^{\prime}}\left(\zeta_{2}\right) H_{n}\left(\zeta_{2}\right) e^{-\zeta_{2} 2 / 2} d y_{2} \quad(21)
\end{aligned}
$$

ここで定常性を用いるとつぎの結果を得る.

$$
B_{x y}(\tau)=\sum_{n^{\prime}=0}^{M} k_{n^{\prime}} \rho_{z^{n^{\prime}}} a_{n^{\prime}} \sqrt{n^{\prime} !}
$$

したがって $R_{x y}(\tau)$ はつぎで与えられる $\left(n^{\prime}\right.$ を改めて $n$ としてもよい).

$$
R_{x y}(\tau)=B_{x y}(\tau)-k_{0} a_{0}=\sum_{n^{\prime}=1}^{M} k_{n^{\prime}} \rho_{z^{n^{\prime}}} a_{n^{\prime}} \sqrt{n^{\prime} !}
$$

上記は線形連立方程式とすればつぎのように表現され る.

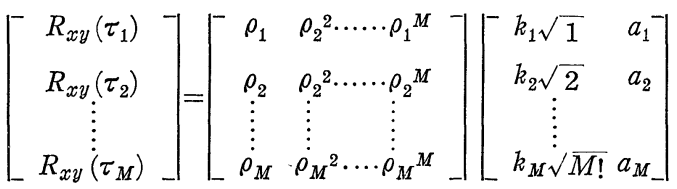

ただし簡単のため $\rho_{z}\left(\tau_{i}\right)$ を $\rho_{i}$ のように書いた。と ころがこの場合 $a_{1}$ のみは, 以前に回帰分析で精度の よい推定值 $\hat{a_{1}}$ が得られているから，つぎのようにし
て（24）式を書き換光てもよい．

$$
\begin{aligned}
& {\left[\begin{array}{c}
R_{x y}\left(\tau_{1}\right)-k_{1} \rho_{1} \hat{a}_{1} \\
\vdots \\
R_{x y}\left(\tau_{M-1}\right)-k_{1} \rho_{M-1} \hat{a_{1}}
\end{array}\right]=\left[\begin{array}{c}
\rho_{1}^{2} \ldots \ldots \ldots \rho_{1}{ }^{M} \\
\vdots \\
\vdots \\
\rho_{M-1}{ }^{2} \cdots \rho_{M-1}{ }^{M}
\end{array}\right]} \\
& \times\left[\begin{array}{cc}
k_{2} \sqrt{2 !} & a_{2} \\
\vdots \\
k_{M} \sqrt{M !} & a_{M}
\end{array}\right]
\end{aligned}
$$

ところが $\rho$ 要素とする行列の取扱いは，(24)，(25) 式も以下に示すようにまったく同様に処理されるので， 解法としての難易の差はない。 また (23) 式の条件式 を未知数より多くとり, 重回帰モデルとして考劣るこ そは $\rho_{z}^{n}\left(\tau_{i}\right)$ の項の存在するのと誤差項が $\tau_{i}=0$ 沉 近い湮ど大きいことなどからあまり適当でないと考兄 る.むしろ連立方程式として（24）または（25）式を とき,これをいくつかの $\tau$ の組について行ない, 最後 に解を平均して精度を高めるべきと考える.よって連 立方程式の解法について考察を加える。

\section{$3 \cdot 2 a_{n}$ を求める連立方程式の代数的解法}

入力は正規定常過程と仮定しているので,つぎの条 件が成立する.

$$
\begin{aligned}
1= & \rho(0)>\rho\left(\tau_{1}\right)>\rho\left(\tau_{2}\right)>\cdots \cdots>\rho\left(\tau_{M}\right) \\
& \left(0<\tau_{1}<\tau_{2}<\cdots<\tau_{M}\right)
\end{aligned}
$$

この条件により (24), (25) 式の行列は階数を多くす ると特異行列に近くなるので（直観的には自明である， が後に示す),これら方程式を直接的に計算機でとくの. は精度上あまり適当でなく, 代数解析的に解を求めた 後計算機によるべきものと考光る。な执記号の便宜上 (24) 式の形の式の解法を以下に示す.

(24) 式の行列を $P_{M}$ と書くと, Vandermonde の, 定理 ${ }^{3)}$ 用い行列式 $\left|P_{M}\right|$ はつぎのようになる.

$$
\begin{aligned}
\left|P_{M}\right| & =\prod_{i=1}^{M} \rho_{i} \prod_{l>k}\left(\rho_{l}-\rho_{k}\right) . \\
\quad(l & =2, \cdots, M, k=1, \cdots, M-1)
\end{aligned}
$$

また（25）式の行列を $P_{M-1}{ }^{\prime}$ で示すと, 同様にして,

$$
\left|P_{M-1}{ }^{\prime}\right|=\prod_{i=1}^{M-1} \rho_{i}^{2} \prod_{l>k}\left(\rho_{l}-\rho_{k}\right)
$$

したがって今後の考察は（24）式のみに限定するが， 手法的には（25）式にも使用できる.

さて（27）式よりわかると特り，条件（26）式によ り $\left|P_{M}\right|$ の絶対值は $M$ とともに減少するが有限項で打 切る限り零ではないこと,すなわち行列 $P_{M}$ は非特異 で逆が存在することがわかる. また行列式 $\left|P_{M}\right|$ の符 号は $1 / 2 M(M-1)$ が奇数ならば負,偶数ならば正とな る. 実際の計算では $M$ を大にすると $\left|P_{M}\right|$ が零に近付 くから，直接に電子計算機で (24) 式を処理するのは 誤差の点で不適当と考兄る。この誤差を除去するため, 以下に $P_{M}$ の逆行列を求める. 
逆行列 $P_{M}{ }^{-1}$ の $j$ 行 $i$ 列の要素を $p^{j i}$ と書けば, こ 水は行列 $P_{M}$ の $i$ 行 $j$ 列の要素 $p_{i j}$ の余因数行列 $P_{i j}$ により一般に次式で与光られる。

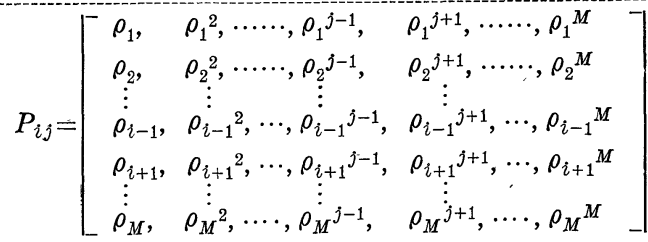

(30) 式右辺の行列式は Vandermonde の行列式の変 形であり，次式の形に㷌着される。

$$
P_{i j}=\frac{1}{\rho_{i}} \prod_{s=1}^{M} \rho_{s} \cdot \prod_{\substack{l>k \\ l \neq i \\ k \neq i}}\left(\rho_{l}-\rho_{k}\right) \cdot S_{M-j}
$$

ここで $S_{M-j}$ は,

$$
S_{M-j}=\sum_{t_{1}, t_{2}, t_{M-j}} \rho_{t_{1}} \rho_{t_{2}} \cdots \rho_{t_{M-j}}\left(t_{1} \neq t_{2} \neq \cdots \neq t_{M-j}\right)
$$

したがって逆行列の要素 $p^{j i}$ は次式で与えられる。

$$
\begin{aligned}
& p^{j i}=(-1)^{i+j} \frac{\frac{1}{\rho_{i}} \prod_{s=1}^{M} \rho_{s} \cdot \prod_{\substack{l>k \\
\neq i}}\left(\rho_{l}-\rho_{k}\right) \cdot \sum_{t_{1} \cdot t_{2}, \cdots, t_{M-j}} \rho_{t_{1}} \rho_{t_{2}} \cdots \rho_{t_{M-j}}}{\prod_{s=1}^{M} \rho_{s} \cdot \prod_{l>k}\left(\rho_{l}-\rho_{k}\right)} \\
& =(-1)^{i+j} \frac{1}{\rho_{i}} \sum_{t_{1}, \cdots, t_{M-j}} \rho_{t_{1}} \cdots \rho_{t_{M-j}} \\
& \cdot \frac{1}{\prod_{l>i}\left(\rho_{l}-\rho_{i}\right) \prod_{i>k}\left(\rho_{i}-\rho_{k}\right)}
\end{aligned}
$$

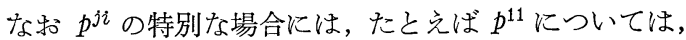

(33) 式を用いなくても直接つぎのように計算できて

(33）式と一致する.

$$
\begin{aligned}
P_{11} & =\left|\begin{array}{cc}
\rho_{2}{ }^{2} \cdots \cdots \rho_{2}{ }^{M} \\
\vdots & \vdots \\
\vdots & \vdots \\
\rho_{M}{ }^{2} \cdots \rho_{M}
\end{array}\right|=\rho_{2}{ }^{2} \rho_{3}{ }^{2} \cdots \rho_{M}{ }^{2} \prod_{l>k}\left(\rho_{l}-\rho_{k}\right) \\
p^{11} & =\frac{p_{11}}{\left|P_{M}\right|}=\frac{\rho_{2}^{2} \cdots \rho_{M}{ }^{2} \prod_{l>k}\left(\rho_{l}-\rho_{k}\right)}{\prod_{\substack{M \\
\neq 1}}^{M} \rho_{t} \prod_{l>k}\left(\rho_{l}-\rho_{k}\right)} \\
& =\frac{1}{\rho_{1}} \rho_{2} \rho_{3} \cdots \rho_{M} \frac{1}{\left(\rho_{M}-\rho_{1}\right)\left(\rho_{M-1}-\rho_{1}\right) \cdots\left(\rho_{2}-\rho_{1}\right)}
\end{aligned}
$$

いっぽう (33) 式より計算してみると, $S_{M-j}=\rho_{2} \rho_{3} \cdots$ . $\rho_{M}$ となり同じ結果を得る. $p^{M i} や p^{1 i}$ も (33) 式に よらず簡単に計算できて，結果はとうぜん（33）式に 一致する（付録には $M=5$ のときの逆行列要素を例 題的に示してあるので参照願いたい).

以上のようにして，一般に $a_{j}$ はつぎの形にとかれ た。

$$
a_{j}=\frac{1}{k_{j} \sqrt{j !}} \sum_{i=1}^{M} p^{j i} R_{y x}\left(\tau_{i}\right)(j=1, \cdots, M)
$$

上式から見られると和り， $\left|a_{j}\right|$ はjの大になるに従い る.

$$
p^{j i}=\frac{P_{i j}}{\left|P_{M}\right|}(-1)^{i+j}
$$

ところで余因数 $P_{i j}$ はつぎの形になる。

通常は小さくなると考えられる。これは $R_{x y}$ の形 にも依存するので一般的にはい学ないが， $p^{j i}$ の形と 分母の $\sqrt{j !}$ の存在によりつぎのように説明でさる・ひ とことで表現すると， $p^{j i}$ は $j$ ともに増大するけれ ども $\sqrt{j !}$ の汇うがより大きくなることによる. 付録と 実例を見てもわがる特り， $p^{j i}$ にはつぎの性質があ る、まず条件 (26) 式より，

$$
\left|p^{j 1}\right|<\left|p^{j 2}\right|<\left|p^{j 3}\right|<\cdots \cdots
$$

が大くの場合成立し（後の実例参照）, $\rho$ に関する次 数としては，これらはすべて同一次数ですべて $j$ 乗 のオーダとなる．したがってつぎの関係式も成立する。

$$
\left|p^{1 i}\right|<\left|p^{2 i}\right|<\left|p^{3 i}\right|<\cdots \cdots
$$

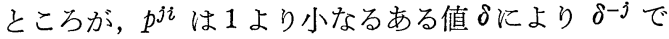
評価されるのに対し, 分母の $\sqrt{j !}$ は Stirling の公式 により $j^{(1 / 2) j} \cdot(2 \pi j)^{1 / 4} \cdot e^{-j / 2}$ で評価される. $1 / \delta=Q$ が どんなに大きくても， $Q^{j}$ と $\sqrt{j !}$ とでは対数をとって 比較することにより, $\sqrt{j !}$ のほらが $j$ とともにより増 大するのがわかる.よって $\left|a_{j}\right|$ は通常は $j$ の大きい所 ではきわめて小さく無視できると思われる．この事実 に基づいた非線形特性推定方法についても以下で触れ

\section{$3 \cdot 3$ 非線形特性推定の一手法}

以上で求めた（34）式を異なった $\tau_{i}$ の組について 適用し，それぞれの $a_{j}$ を平均して精度を高めた解 $\left(a_{1}, a_{2}, \cdots, a_{M}\right)$ を得たとする。これに $a_{0}$ を付加する。 ちなみに $a_{0}=\varepsilon\{f(z)\}$ であるから， $a_{0}$ はサンプル平 均をとることで求まり（正規定常過程を前提としてい るのでェルゴード性が成立するから），また $a_{1}$ は回帰 分析結果を用いた洼らが精度的によい [ $\left(18^{\prime}\right)$ 式と (25) 式]. ここではかくして得られた $a_{j}$ の推定值のベクト ル $\left(\hat{a_{0}}, \hat{a_{1}}, \hat{a}_{2}, \cdots, \hat{a}_{M}\right)$ より非線形特性を求めることを 考える.1つの有力な方法は， $j$ の大なるとき $a_{j}$ が 極小であることを用い, 有限次元べクトル $\left(\hat{a}_{0}, \hat{a}_{1}, \hat{a_{2}}\right.$, $\left.\cdots, \hat{a}_{M}\right)$ を既知の非線形要素のベクトル $\left(a_{0}, a_{1}, a_{2}, \cdots\right.$, $\left.a_{M}\right)$ と多次元的ななんらかの手法で比較を行なうこ とである.しかしここでは（6）式を用いた方程式 
より $f(z)$ を推定する方法を提案する。ところで（6） 式は定常的な場合にはつぎの形になる。

$$
\begin{aligned}
a_{n} & =\frac{1}{\sqrt{2 \pi n !}} \cdot \frac{1}{\sigma_{z}} \cdot \int_{-\infty}^{\infty} f(z) H_{n}\left(\frac{z-m_{z}}{\sigma_{z}}\right) \\
& \times \exp \left[-\frac{\left(z-m_{z}\right)^{2}}{2 \sigma_{z}^{2}}\right] d z \\
& =\frac{1}{\sqrt{2 \pi n !}} \int_{-\infty}^{\infty} f\left(\zeta \sigma_{z}+m_{z}\right) H_{n}(\zeta) e^{-\zeta^{2 / 2}} d \zeta
\end{aligned}
$$

これを離散化して下記の連立方程式を作る.つまりこ の場合 $e^{-\zeta^{2} / 2}$ が $\zeta$ の増大とともに急速に零に近づく のを考慮して有限区間内で方程式を作るのである.す なわち,

$$
\left.\begin{array}{c}
\hat{a}_{0}=\frac{1}{\sqrt{2 \pi}} \sum_{i=-N}^{N} f\left(\zeta_{i} \hat{\sigma}_{z}+\hat{m}_{z}\right) e^{-\zeta_{2} 2 / 2} \Delta \zeta_{i} \\
\sqrt{2 \pi} \hat{a}_{1}=\sum_{i=-N}^{N} f\left(\zeta_{i} \hat{\sigma}_{z}+\hat{m}_{z}\right) \zeta_{i} e^{-\zeta_{i} 2 / 2} \Delta \zeta_{i} \\
\sqrt{2 \pi n !} \hat{a}_{n}=\sum_{i=-N}^{N} f\left(\zeta_{i} \hat{\sigma}_{z}+\hat{m}_{z}\right) H_{n}\left(\zeta_{i}\right) e^{-\zeta_{2}{ }^{2} / 2} \Delta \zeta_{i}
\end{array}\right\}
$$

上式において $\hat{a}_{n}$ は $n$ の増大とともに小となるが $\sqrt{2 \pi n !} \hat{a}_{n}$ を用いるので， $N$ を大きくしても方程式 が無意味になることはない，

さて（37）式なる連立方程式をとくことによって， 各 $\zeta_{i}$ 点つまり各点 $z_{i}(i=-N,-N+1, \cdots, 0 \cdots, N)$ に 拉け死非線形関数值 $f\left(z_{i}\right)$ の值を得ることができる. そしてこの結果につき折線近似または平滑近似して $f(z)$ を推定し得る.な括この連立方程式の非特異性 が必要であるが, これは $H_{n}(\zeta) e^{-\zeta^{2 / 2}}$ の連続関数で あることから考えて，かりにある $\zeta_{i}$ の組では特異行 列になったとしても，別の $\zeta_{i}$ の組を適当に選定する ことによりつねに非特異化可能であるからこの点の問 題はない.

以上でゼロメモり形の非線形要素の特性推定の一手 法が与えられた. ベクトル $\left(a_{0}, a_{1}, \cdots, a_{M}\right)$ の比較によ る非線形要素のパターン認識の方法は, 今後検討した i.

\section{4. 非線形度チェックの簡便計算法と数値 計算法例}

ここでは, 非線形特性そのものの推定問題から離れ て,$a_{j}{ }^{2}$ の最初の部分すなわち $a_{1}{ }^{2}, a_{2}{ }^{2}, a_{3}{ }^{2}$ をはあくす る簡便法について述べ，数值計算例も併せ示した（非 線形度は $R_{x}(0)-a_{1}{ }^{2}$ で汇ぼつかめるが, $a_{2}{ }^{2}$ も求め たいときがある)。

さて $a_{j}{ }^{2}$ の最初の部分の推定法はつぎのと呿りであ る.おず (9) 式に着目し, 無限和を有限和で近似し てつぎの連立方程式を作る。

$$
\left[\begin{array}{c}
R_{x}\left(\tau_{1}\right) \\
R_{x}\left(\tau_{2}\right) \\
\vdots \\
R_{x}\left(\tau_{M}\right)
\end{array}\right]=\left[\begin{array}{c}
\rho_{1} \cdots \rho_{1}{ }^{M} \\
\rho_{2} \cdots \rho_{2}{ }^{M} \\
\vdots \\
\vdots \\
\rho_{M} \cdots \rho_{M}{ }^{M}
\end{array}\right]\left[\begin{array}{c}
a_{1}{ }^{2} \\
a_{2}{ }^{2} \\
\vdots \\
\vdots \\
a^{2}{ }_{M}
\end{array}\right]
$$

実際の計算では， $\tau=0$ の近傍について有限近似をす るのは無理で, この簡便法は直接的に $\tau=0$ 近傍の重 要情報を取出さない欠点がある.なお $R_{x}(\tau), \rho_{z}(\tau)$ は 実験的に求めて既知とする。この方程式の解は，(33) 式の逆行列要素を転用すれば簡単に求まる.

実例として，この方法により $a_{j}{ }^{2}$ の最初の部分がど の位の精度で求るものが, リレー要素を例にとり考察 してみる・ただし実際の実験的検討を行なら機会がな いので，ここでは $\rho_{z}(\tau)$ および $R_{x}(\tau)$ の真值が求ま った理想的な場合を仮定して検討した（したがって実 測値ではこの場合より精度は多少落ちることになる). すなわち実用上は $\rho_{z}(\tau)$ および $R_{x}(\tau)$ の観測值を用 いるべきであるが，ここでは理論上既知である次式を 用いた。

$$
R_{x}(\tau)=\frac{2 l^{2}}{\pi} \sin ^{-1} \rho_{z}(\tau)
$$

ちなみにヒステリシスや不感帯のない理想的なリレー 要素の入力の自己相関と出力の自己相関との間には, 入力が正規確率過程の場合には (39) 式の関係が成立 するのが Price の定理により証明されている．この 関係式を用いれば，リレー要素の場合の $a_{n}$ は (6) 式で計算する代わりに， $R_{x}(\tau)$ を $\rho_{z}(\tau)$ のベキ級数 に展開することで簡単に求められる.すなわち，

$$
R_{x}(\tau)=\frac{2 l^{2}}{\pi} \arcsin \rho_{z}(\tau)=\sum_{n=1}^{\infty} a_{n}{ }^{2} \rho_{z}(\tau)
$$

と和いて有名な $\sin ^{-1} \rho_{z}$ の高次導関数漸化式を用いれ ばつぎのようになる。つまり，

$$
R_{x}(\tau)=\frac{2 l^{2}}{\pi} \sum_{x=0}^{\infty} \frac{R_{x}^{(n)}\left(\rho_{z}=0\right)}{n !} \rho_{z}^{n}
$$

を考慮して $a_{n}{ }^{2}$ はつぎのように定められる。

$$
\begin{aligned}
a_{n}{ }^{2} & =\frac{2 l^{2}}{\pi} \frac{(2 m-1)}{2^{2} \cdot 4^{2} \cdots(2 m-2)^{2} \cdot 2} \frac{!}{m \cdot(2 m+1)} \\
n & =2 m+1 \text { のとき } \\
a_{n}{ }^{2} & =0 \quad n=2 m \text { のとき }
\end{aligned}
$$

簡単のためリレー要素の利得 $l=1$ としてこの場合 の $a_{n}{ }^{2}$ をいつか求めてみるとつぎのと特りである.

$$
a_{1}{ }^{2}=0.636, a_{3}{ }^{2}=0.106, a_{5}{ }^{2}=0.0476
$$

つぎに相関の真值がわかったとして，簡便法 (38) 式でどの程度の精度で $a_{1}^{2}$ らが求るかしらべてみる. 実例として $M=5$ としてみる。な和 (38) 式を用い るときは， $\rho_{1}, \cdots, \rho_{5}$ の選定につぎのような配虑が必 要である.

たと党ば 5 個の $の$ 選定をかりに, $\rho_{0}=1, \rho_{1}=e^{-1 / 10}$, 
$\rho_{2}=e^{-2 / 10}, \rho_{3}=e^{-3 / 10}, \rho_{4}=e^{-4 / 10}$ とすると，(39) 式よ り $R_{x}(0)=1, R_{x}(2)=0.611, R_{x}(3)=0.531, R_{x}(4)$ $=0.467$ となる.このような $\rho_{i}$ の選定に基づくデー 夕条件から， $a_{\text {j }}^{2}$ を求めるとどうなるか検討してみよ ら。いまかりに $a_{7}$ まで考光て無限和と有限和の差を 考えてみると， $\sum_{j=1}^{7} a_{j}{ }^{2}=0.8182$ で $\sum_{j=1}^{\infty} a_{j}^{2}=1$ とには 相当の差がある.したがってこのような $\rho_{i}$ の選定で (38) 式をといても，見当違いの結果しか得られない. つまり $\tau=0$ の付近に性線形性の情報が集積するの であるが，この近傍から簡便法の連立方程式を作成す るのは不適当なのである.この例で $R(4)$ の両辺を 比較してみると $\sum_{j=1}^{5} a_{j}^{2} \rho^{j}=0.435$ となり, 左右両辺の 值が漸く $10 \%$ 以内になる.

上記の例からもわかると新り，要するに無限項を有 限項で打切る䛊差の程度を予めある範囲内に押えてお く必要があり，実は $\rho_{1}$ の值を 0.5 以上に選定すると よい推定を与えないのが種々の計算例から認められた. な和この場合のように，非線形特性の原点に関し対 称であるのがもしも既知であれば，(38) 式の代わり につぎの式を用いればよい。

$$
\left.\begin{array}{c}
R_{x}\left(\tau_{1}\right)=a_{1}{ }^{2} \rho_{1}+a_{3}{ }^{2} \rho_{1}{ }^{3}+a_{5}{ }^{2} \rho_{1}{ }^{5}+a_{7}{ }^{2} \rho_{1}{ }^{7}+a_{9}{ }^{2} \rho_{1}{ }^{9} \\
R_{x}\left(\tau_{2}\right)=a_{1}{ }^{2} \rho_{2}+a_{3}{ }^{2} \rho_{2}{ }^{3}+a_{5}{ }^{2} \rho_{2}{ }^{5}+a_{7}{ }^{2} \rho_{2}{ }^{7}+a_{9}{ }^{2} \rho_{2}{ }^{9} \\
\vdots \\
\dot{R}_{x}\left(\tau_{5}\right)=a_{1}{ }^{2} \rho_{5}+a_{3}{ }^{2} \rho_{5}{ }^{3}+a_{5}{ }^{2} \rho_{5}{ }^{5}+a_{7}{ }^{2} \rho_{5}{ }^{7}+a_{9}{ }^{2} \rho_{5}{ }^{9}
\end{array}\right\}
$$

この連立方程式の代数的解法は，前述とまったく同様 にして行なうことができ，ここでは得られた逆行列要 素 $p^{j i}$ の一般式を示すにとどめる.

$$
\begin{aligned}
p^{j i} & =(-1)^{i+j} \frac{1}{\rho_{i}} \sum_{t_{1}, t_{2}, \cdots, t_{M-j}} \rho_{t_{1}}{ }^{2} \rho_{t_{2}}{ }^{2} \ldots \rho_{t_{M-j}}{ }^{2} \\
& \times \frac{1}{\prod_{l>i}\left(\rho_{l}^{2}-\rho_{i}^{2}\right) \prod\left(\rho_{i>k}^{2}-\rho_{k}^{2}\right)}
\end{aligned}
$$

さて話しを戻して，無限項を有限近似するさいの䛊 差を少なくするよう $\rho_{i}$ を選定することは重要であるが， $\rho_{i}$ を必要以上に小さくとると実際面では逆に周期的 ノイズに埋没されて， $a_{n}{ }^{2}$ の推定精度が悪くなる。し たがって適切な $\rho_{i}$ の選定はかなりむずかしい.これ がこの簡便法の短所である.さて $\rho_{i}$ の選定は場合に 応じて個別的に考えるべきことであるが，実際上 0.3 〜 0.1 の間にとることが多くなると考える.ここでは 実例として $\rho_{1}=0.5, \rho_{2}=0.4, \rho_{3}=0.3, \rho_{4}=0.2, \rho_{5}$ $=0.1$ と選定し, ゼロメモリ理想リレー要素であるの が既知の場合につき，計算尺にて計算した結果をつぎ に示与.

一一(簡便法によるリレー要素非線形度計算例, $\left.\rho_{1}=0.5, \rho_{2}=0.4, \rho_{3}=0.3, \rho_{4}=0.2, \rho_{1}=0.1\right)$

$$
\begin{array}{rl}
p^{11}= & 0.0159, \quad p^{12}=-0.198, \quad p^{13}=1.22, \quad p^{14}=- \\
& 4.76, \quad p^{15}=16.65 \\
a_{1}{ }^{2} & 0.0159 \times 0.334-0.198 \times 0.262+1.22 \times 0.193 \\
- & 4.76 \times 0.128+16.65 \times 0.0637 \\
= & 0.00535-0.0521+0.236-0.609+1.06 \\
\doteqdot & 0.64
\end{array}
$$

これは $a_{1}{ }^{2}$ の真值 0.636 とよく一致している. $a_{3}{ }^{2}$ の 推定はつぎのと拈りである。

$$
\begin{aligned}
p^{21} & =2.2618, \quad p^{22}=27.8, \quad p^{23}=-161, \quad p^{24}=577, \\
p^{25} & =-771.9 \\
a_{3}{ }^{2} & =-0.334 \times 2.2618+0.262 \times 27.8-0.193 \times 161 \\
& +0.128 \times 577-0.0637 \times 771.9 \\
& =-0.756+7.28-31.1+73.8-49.1=0.1
\end{aligned}
$$

これは $a_{3}^{2}$ の真值 0.106 とほぼ一致する.

$a_{5}{ }^{2}$ よりも高次の $a_{n}{ }^{2}$ の值は, この 5 元方程式では 䛊差が大きく，意味ある推定が行なえなかった。これ は逆行列要素がつぎのようなぼう大な值となるためで ある・

$p^{31}=668, p^{32}=-882, p^{33}=4530, p^{34}=-10750, p^{35}$ $=11170, \quad p^{41}=-7460, \quad p^{42}=8610, \quad p^{43}=-34200$, $p^{44}=67300, \quad p^{45}=-62400, p^{51}=2.483 \times 10^{4}, \quad p^{52}=$ $-2.204 \times 10^{4}, p^{53}=7.44 \times 10^{4}, p^{54}=-1.32 \times 10^{5}$, $p^{55}=1.157 \times 10^{5}$

ここで $p^{3 i}$ は $a_{5}{ }^{2}$ に対応し, $p^{4 i}$ は $a_{7}{ }^{2}$ に $p^{5 i}$ は $a_{9}{ }^{2}$ に対応する。

上記の結果より簡便法について類推すると， $\rho_{i}$ とし て $0.4 〜 0.1$ の間に $M$ 個を選び方程式を作れば，最初 の数個は $a_{n}{ }^{2}$ の真值とよく一致しそうに思われる. そして逆行列の要素の值の大きさ, および $p^{j i} R_{x}\left(\tau_{i}\right)$ の各項のバランスに注意をはらえば，各推定值を信用 してよいかどらかの判断は可能なのである.これは種 々の実際的検討の結果得た結論である.しかしながら 簡便法は理論的裏付けが不十分であるから，本来は (34) 式による正統的方法を用いるべきであろう。

\section{5. 結}

\section{言}

以上で，ゼロメモリ形非線形要素の定常運転時にお ける特性同定一手法について述べた，測定される非線 形要素 $f(z)$ に対し, 基準用非線形変換素子 $g(z)$ は 固定したままでよいのが本方法の特長と考える．ただ し $g(z)$ は $M$ 次多項式 (エルミート多項式より誘導さ れる) であり, 専用ディジタル機構で実現されること になる。

また非線度の尺度である $a_{n}{ }^{2}$ の最初の部分の推定簡 便法について述べた.これには誤差の問題等根本的な 欠点もあり，数值計算例も併せ述べたが，精密法では 
なにゆ兄 3. のようなデータ処理機構 $g(z)$ が必要か とゆうことがこれにより逆济明確になったと考劣る。 終わりに種々討論いただいた日立京浜工業専門学校大 金正芳教授に謝意を表する。

\section{参考文献}

1) H. Cramer : Mathematical Methods of Statistics, pp. 133-134, Princeton Univ. Press (1949)

2) А. А. Первозванский : Случайные процессы в нелинйных автоматических системах, рp. 37-39, Москва, Ф.М.И. (1962)

3）遠山：行列論, 67/68 (共立全書-1952)

$$
\text { 一付 録—— }
$$

\section{$\boldsymbol{M}=5$ のときの逆行列要素計算結果}

例題として，(33）式の一般式を $M=5$ の場合につ いて示す. 全要素を記載するのもむだであるから， 3 列目の要素を例として, $p^{13}, p^{23}, p^{33}, p^{43}, p^{53}$ のみ示し た. 他の諸要素は番号を置換すれば, 簡単に求められ
る・

$$
\begin{aligned}
p^{13} & =\frac{1}{\rho_{3}} \rho_{1} \rho_{2} \rho_{4} \rho_{5} \frac{1}{\left(\rho_{5}-\rho_{3}\right)\left(\rho_{4}-\rho_{3}\right)\left(\rho_{3}-\rho_{2}\right)\left(\rho_{3}-\rho_{1}\right)} \\
p^{23} & =-\frac{1}{\rho_{3}}\left[\rho_{1} \rho_{2} \rho_{4}+\rho_{2} \rho_{4} \rho_{5}+\rho_{1} \rho_{4} \rho_{5}+\rho_{1} \rho_{2} \rho_{5}\right] \\
& \times \frac{1}{\left(\rho_{5}-\rho_{3}\right)\left(\rho_{4}-\rho_{3}\right)\left(\rho_{3}-\rho_{2}\right)\left(\rho_{3}-\rho_{1}\right)} \\
p^{33} & =\frac{1}{\rho_{3}}\left[\rho_{1} \rho_{2}+\rho_{1} \rho_{4}+\rho_{1} \rho_{5}+\rho_{2} \rho_{4}+\rho_{2} \rho_{5}+\rho_{4} \rho_{5}\right] \\
& \times \frac{1}{\left(\rho_{5}-\rho_{3}\right)\left(\rho_{4}-\rho_{3}\right)\left(\rho_{3}-\rho_{2}\right)\left(\rho_{3}-\rho_{1}\right)} \\
p^{43} & =-\frac{1}{\rho_{3}}\left[\rho_{1}+\rho_{2}+\rho_{4}+\rho_{5}\right] \\
& \times \frac{1}{\left(\rho_{5}-\rho_{3}\right)\left(\rho_{4}-\rho_{3}\right)\left(\rho_{3}-\rho_{2}\right)\left(\rho_{3}-\rho_{1}\right)} \\
p^{53} & =\frac{1}{\rho_{3}} \cdot \frac{1}{\left(\rho_{5}-\rho_{3}\right)\left(\rho_{4}-\rho_{3}\right)\left(\rho_{3}-\rho_{2}\right)\left(\rho_{3}-\rho_{1}\right)}
\end{aligned}
$$

ここで付号は $(-1)^{i+j}$ で定るのに注意する. 